\title{
Pathology of Gout in Commercial Broiler Chicken
}

\author{
M. Sathiyaseelan ${ }^{1}$, R. Kumar ${ }^{1}$, A.W. Lakkawar ${ }^{1}$, M.G. Nair ${ }^{1 *}$, \\ J. Thanislass ${ }^{2}$ and K.C. Varshney ${ }^{1}$ \\ ${ }^{1}$ Department of Veterinary Pathology, Rajiv Gandhi Institute of Veterinary Education and \\ Research, Puducherry-605009, India \\ ${ }^{2}$ Department of Biochemistry, Rajiv Gandhi Institute of Veterinary Education and Research, \\ Puducherry-605009, India \\ *Corresponding author
}

\begin{tabular}{|c|c|}
\hline & A B S T R A C T \\
\hline $\begin{array}{l}\text { K e y w o r d s } \\
\text { Gout, Pathology, } \\
\text { Broiler chicken }\end{array}$ & \multirow{3}{*}{$\begin{array}{l}\text { Avian urolithiasis, or known as gout, is resultant to kidney damage from any of a number } \\
\text { of potential cause, namely infectious or nutritional disease, ingestion of toxins, or a } \\
\text { combination of factors. The present study reports pathomorphology of visceral Gout in } \\
\text { commercial broiler chicken from Puducherry and Tamil Nadu region in India. A total of } \\
120 \text { kidney samples were collected for gross and histopathological examination. } 24 \text { ( } 20 \%) \\
\text { samples showed gross changes of visceral gout. Microscopically, gout was recorded in } 28 \\
\text { ( } 23.33 \%) \text { cases. The renal lesions characterized by varying degree of tubular degeneration } \\
\text { and necrosis. In addition, radiating fine needle shaped crystals were noticed in the lumen } \\
\text { and interstitium of renal parenchyma. De Galantha staining method on tissue sections of } \\
\text { affected organs confirmed the cases as gout. }\end{array}$} \\
\hline Article Info & \\
\hline $\begin{array}{l}\text { Accepted: } \\
\text { 17 June } 2018 \\
\text { Available Online: } \\
10 \text { July } 2018\end{array}$ & \\
\hline
\end{tabular}

\section{Introduction}

Renal diseases have been shown to be fairly common in avian species. In poultry, as much as $29.6 \%$ of all disease conditions had abnormal pathology associated with or attributable to renal disorders (Siller, 1981). The cause for the development of kidney lesions is usually multi factorial and may be attributed to nutritional deficiencies, managemental problems, toxins and infectious agents. In addition, the urinary system of poultry is so unique that the blood can be directed from the lower limbs straight into the renal parenchyma. This may increase the effect of nephrotoxic drugs and/or enhance elimination by taking the compound directly to the kidneys (http://avianmedicine.net/ content/uploads/kidneys.pdf).

In poultry, renal diseases may lead to gout, which can further damage the kidneys or additional body systems. Gout is more a sign of renal damage than a distinct disease. Several outbreaks of gout were reported in commercial broilers in India during 2011 and 2012 , causing up to $40 \%$ mortality in the birds (Bulbule et al., 2013). It is a metabolic disorder resulting in hyperuricemia and the deposition of uric acid or urates in tissues. The 
nutritional or metabolic causes of gout include excess dietary calcium, high protein diet, excess salt, low phosphorus, imbalance between $\mathrm{Ca}-\mathrm{P}$ levels, adulteration of feed with urea and deficiencies of vitamin A and D. Water deprivation followed by over dosages of certain drugs like sulphas and the antibiotic aminoglycosides often causes kidney damage. In addition, some managemental stress factors including high brooding temperature and higher level of ammonia concentration in the shed can also cause high mortality due to gout (Bulbule et al., 2014). The role of mycotoxins and phytotoxins in the causation of kidney damage and gout in poultry is well documented. Primary infectious nephritis due to bacterial agents does not appear to be common in poultry.

The present paper describes the occurrence and pathology of gout and associated renal changes in commercial broiler chicken.

\section{Materials and Methods}

The study was carried out on broiler kidney samples collected from various farms located at Udumalpet, Coimbatore, Salem and Puducherry, Southern part of India. The age of the birds varied from day-old to six weeks. A total of 240 kidney samples (both left and right) from 120 broiler birds were collected for examination. Kidney samples with lesions were included for the study.

Representative tissue samples fixed in $10 \%$ $\mathrm{NBF}$ and in absolute alcohol were processed by paraffin embedding technique for microtomy and 4-5 $\mu \mathrm{m}$ thick sections were prepared and stained by routine Haematoxylin and Eosin (H\&E) for detailed histopathological studies as described by Luna (1968). Parallel sections from tissue samples fixed in absolute alcohol were also stained by DeGalantha method for gout.

\section{Results and Discussion}

Renal diseases have been shown to be fairly common in avian species. Pathological lesions in the kidneys are marked but often overlooked in routine post-mortem examination in spite of the fact that they can greatly help in reaching a conclusive diagnosis. Hence, the present study was aimed to investigate the occurrence and pathological characterization of gout in broiler chickens from slaughtered and necropsied cases.

Gout is a metabolic disorder resulting in hyperuricemia and the deposition of uric acid or urates in tissues. Grossly, gout was recorded in 24/120 (20\%) cases and it was characterized by swollen pale kidneys with urate deposits and dilated ureters with chalky white material (Fig. 1). The other noticeable findings observed was presence of chalky white masses surrounding the heart, kidneys, liver and other organs (Fig. 2). Microscopically, gout was recorded in 28/120 $(23.33 \%)$ cases on both the kidneys. The kidneys showed severe lesions characterized by moderate to severe tubular dilation, necrosis and large deposits of radiating fine needle shaped crystals in the tubular lumen (Fig. 3) and in the interstitium and also in myocardium (Fig. 4). These deposits were surrounded by a zone of granulomatous inflammation (Fig. 5). The crystals appeared black against a yellow background on DeGalantha staining confirming theme to be of urates and the cases of gout (Fig. 6). The gross and histopathological features observed in the present study concur with the observations of earlier workers (Ansar et al., 2004; Feizi et al., 2011; Auda, 2013).

Gout is multifactorial in origin. It is rather the result of kidney damage from any of a number of potential causes, which can be infectious, nutritional, toxic, poor management or possibly a combination of factors. 


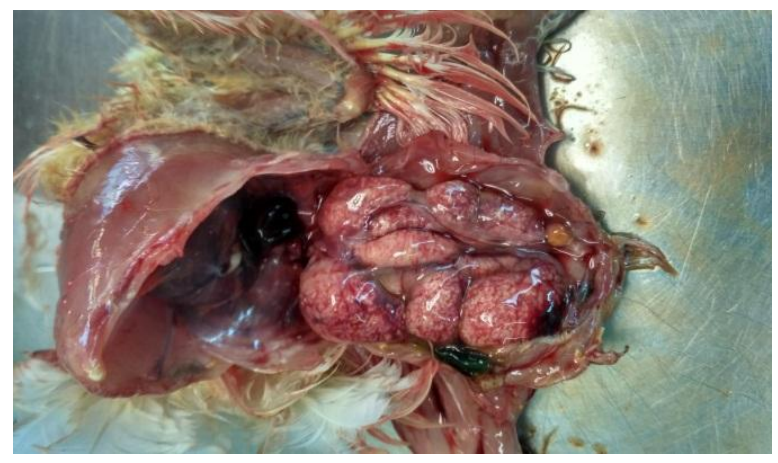

Fig.1 Swollen kidneys with chalky white deposits

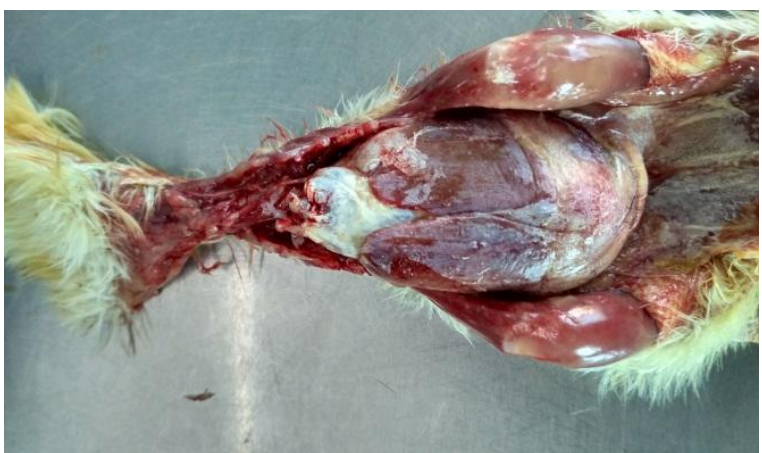

Fig.2 Chalky white deposits noticed in the pericardial sac and surface of liver.

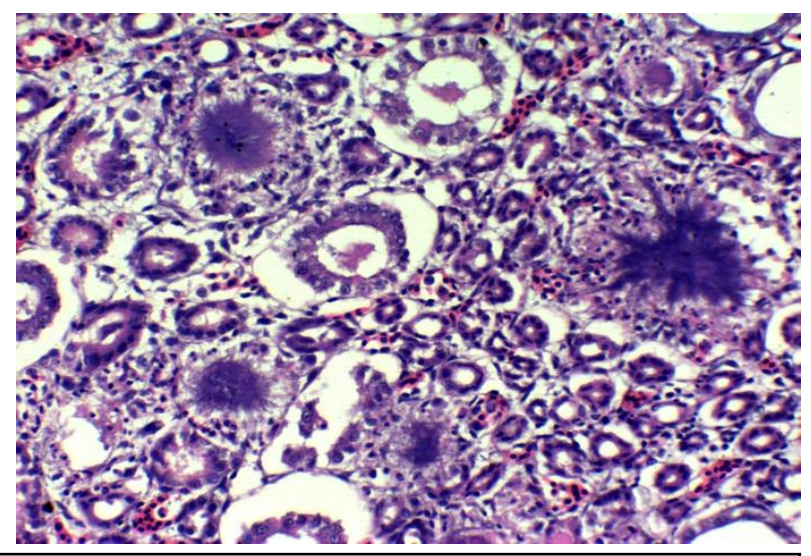

Fig.3 Kidney-Presence of fine needle shaped urate crystals in tubules. H\&E x 400

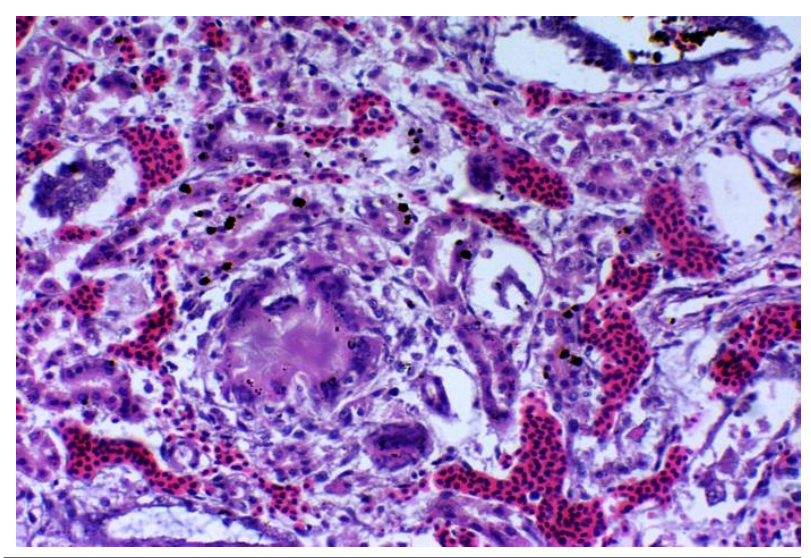

Fig.5 Kidney-Urate granuloma surrounded by zone of hyperemia. H\&E x400

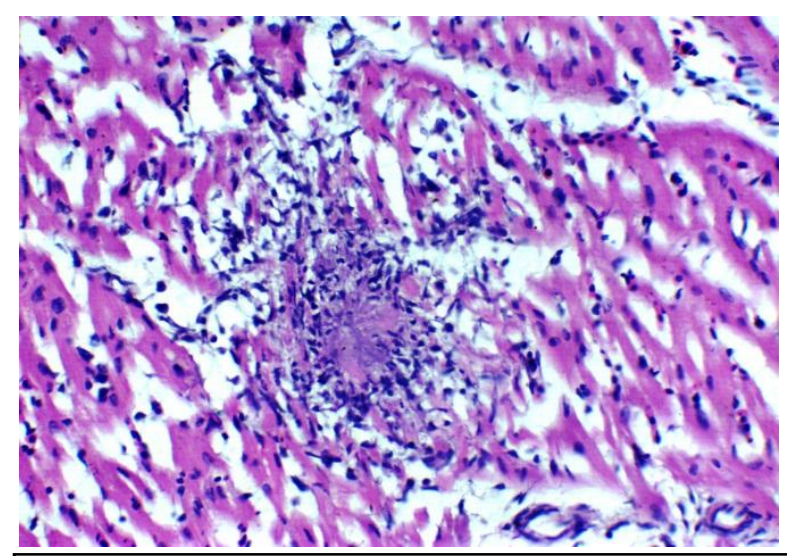

Fig.4 Heart- Presence of fine needle shaped urate crystals. H\&E x 400

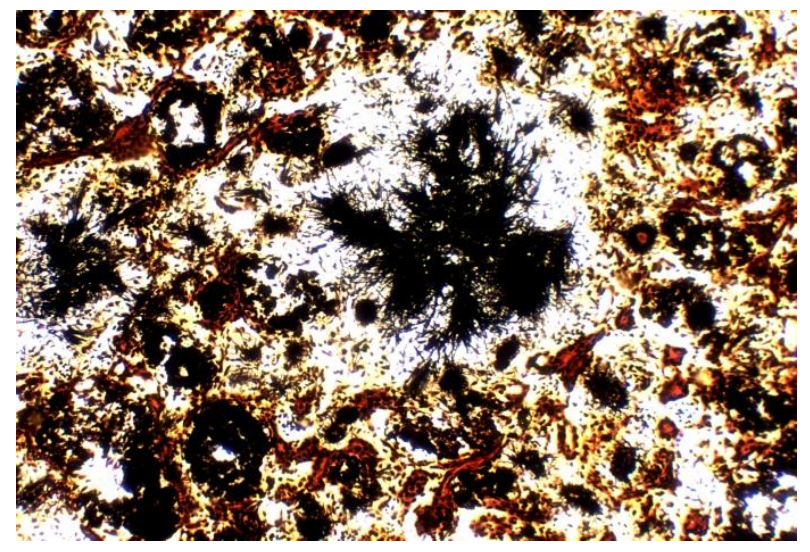

Fig.6 Kidney-Fine needle shaped black urate deposits. De Galantha x200 
The nutritional or metabolic causes of gout include excess of dietary calcium (Feizi et al., 2011), high protein diet (Singh and Ghosh, 2014), excess salt (Sodhi et al., 2008), low phosphorus, imbalance between $\mathrm{Ca}-\mathrm{P}$ levels (Ansar et al., 2004), adulteration of feed with urea and vitamin A and D deficiency. Water deprivation followed by over dosages of certain drugs like sulphas and the antibiotic aminoglycosides (Gentamicin) often causes gout (Javed et al., 2013). In addition, it is mentioned that managemental stress factors including high brooding temperature and higher level of ammonia concentration in the shed cause high mortality due to gout (Bulbule et al., 2014). The authors have further said that primary infectious nephritis due to bacterial agents does not appear to be common in poultry. E. coli and Salmonella have occasionally been isolated from cases of pyelonephritis, but the infection is likely secondary. The role of mycotoxins in the causation of gout is well documented and has been discussed under tubular changes.

In addition to the above mentioned etiological agents, the specific viral diseases often reported to be associated with kidney damage are Infectious bronchitis virus, avian nephritis virus and disease caused by chicken astro virus. According to Bulbule et al., (2013), several outbreaks of gout were reported in commercial broilers in India during 2011 and 2012 , causing up to $40 \%$ mortality in the birds. According to the authors, the managemental and nutritional causes were not involved in the causation of gout. The infectious agents such as chicken astrovirus, avian nephritis virus and infectious bronchitis virus were detected in gout cases. In the present study, ANV was detected in two gout cases. Similarly, Eswaran et al., (2014) from Tamil Nadu and Ghodasara et al., (2015) also detected ANV in clinical cases of gout from Raipur, Chhattisgarh.
In the present study, the occurrence of gout was more in birds less than 3 weeks of age than 3-6 weeks of age. Similar observations were also made by Singh et al., (2013). In addition the authors have recorded more cases of gout during colder months

\section{Acknowledgement}

The authors were thankful to the Dean, Rajiv Gandhi Institute of Veterinary Education and Research, Puducherry, India for providing the necessary facilities for carrying out the research work.

\section{References}

Ansar, M., Khan, S.A., Chaudhary, Z.I., Mian1, N.A., Tipu, M.Y. and Rai, M.F. (2004).Effect of high dietary calcium and low phosphorus on urinary system of broiler chicks, Pakistan Vet. J., 24(3): 113-116.

Auda, A.D. (2013). Pathological study of the experimentally visceral gout in Nasiriya city broilers. Journal of University of Thi-Qar, 8(3): 1-7

Bulbule, N.R., Mandakhalikar, K.D., Kapgate, S.S., Deshmukh, V.V., Schat, K.A. and Chawak, M.M. (2013).Role of chicken astrovirus as a causative agent of gout in commercial broilers in India. Avian Pathol., 42(5): 464-473.

Bulbule NR, Kapgate SS, Chawak MM. (2014). Infectious causes of gout in chickens. Advances in Animal and Veterinary Sciences., 2(4): 255-260

Eswaran, M. A., Sukumar, K., Balasubramaniam, A. and Sumitha, P. (2014).Detection of avian nephritis virus infection in commercial broiler chickens. XXXI Annual conference of Indian poultry science association and National symposium on Poultry production for global trade. Pp.244. 
Feizi, A., Dadian, F. and Nazeri, M. (2011).Evaluation the Effect of Dietary Calcium Percentage on Incidence of Gout syndrome in Broiler Chicks. Aust. J. Basic Appl. Sci., 5(11): 1750-1755.

Ghodasara, P.D., Prajapati, K.S., Ghodasara, D.J., Joshi, B.P., Thakkar, H., Banerjee, J. and Pal, J.K. (2015). Isolation and detection of avian nephritis virus by RT-PCR from commercial broiler flocks affected with visceral gout in India. Indian $J$. Vet.Pathol.,39(1): 54-57.

http://avianmedicine.net/content/uploads/kidn eys.pdf accessed on 01.02.2015

Luna, L. G. (1968). Manual of histologic staining methods of the Armed Forces Institute of Pathology.3rd ed.,
McGraw Hill, New York, U.S.A.

Siller W.G. (1981). Renal pathology of the fowl- A review. Avian Patho. 10:187262

Singh, N. and Ghosh, R.C. (2014). Pathology of gout induced by high protein diets in growing broilers. Asian J.Anim. Sci, 9(2): 149-153.

Singh N, Ghosh, RC, Singh A. (2013). Prevalence and haematobiochemical studies on naturally occurring gout in Chhattisgarh. Adv. Anim. Vet. Sci.; 1(38):9-11

Sodhi S, Brar RS, Banga HS, Nagra SS. (2008). Pathobiochemical studies on experimentally induced gout by administration of sodium bicarbonate in broilers. Toxicol. Int..; 15:117-20.

\section{How to cite this article:}

Sathiyaseelan, M., R. Kumar, A.W. Lakkawar, M.G. Nair, J. Thanislass, Varshney, K.C. 2018. Pathology of Gout in Commercial Broiler Chicken. Int.J.Curr.Microbiol.App.Sci. 7(07): 24142417. doi: https://doi.org/10.20546/ijcmas.2018.707.282 